\title{
The Role of Nurses in Divorce
}

\section{Andria Pragholapati}

Yuwana and Maramis (1990) say that mental disorders in some urban areas show that problems in married life are the factors most often associated with mental disorders and women are more affected than men, this is possible because the nature and openness of women make themselves easy affected by changes from outside. Based on these studies that marriage affects anxiety, anxiety affects the Coping Strategy, Coping Strategy affects the tendency of mental disorders. The Coping Strategy is constructive when anxiety is used as a warning sign and individuals accept it as a challenge to solve the problem. The destructive Coping Strategy turns off anxiety warnings and does not resolve conflicts, and may use a Coping Strategy that avoids resolution (Stuart, 2013).

Research on adolescents whose parents are divorced or family is not harmonious using emotionally oriented coping (Rahmayanti, 2010). While research conducted in North Sumatra found that coping by families of psychiatric patients who have received adequate treatment prioritizes problem-oriented coping (Islamie, 2011). A similar study by Tegegne, Molla, Wonde \& Jibat (2015), found that the Coping Strategy used by divorced couples is negotiating with each other, presenting problems to the elder, presenting problems to women's care institutions, by informing family/relatives/friends, come to court, and discuss with the environment.

In the practice of mental care standard care that becomes the focus in caring for clients is the maintenance of optimal health and well-being as well as prevention of psychobiological disorders, selfcare limitations or functional disorders associated with mental and emotional distress, deficits in biological, emotional and cognitive symptoms, which are significant, stress emotional or disease components, illness, and disability, changes in self-concept, developmental problems, and changes in life processes, problems related to emotions such as anxiety, anger, sadness, loneliness, and grief, physical symptoms that occur along with changes in psychological function, changes in thinking, perceiving, symbolizing, communicating, and making decisions, difficulties relating to others, behaviors and mental status that indicate the client is dangerous to himself or others or has severe disability, interpersonal, systemic, socio-cultural, spiritual, or environmental conditions environment, or events that affect the mental or emotional well-being of an individual, family, or community, management of symptoms, side effects / toxicity of psychopharmacological interventions, and other aspects of therapeutic programs (Videbeck, 2013).

The role of nurses as providers of nursing care services, nurses have a duty to provide services to clients who experience mental health problems due to divorce. Nurses can provide psychoeducation and psychosocial interventions. Psychosocial Interventions are nursing activities that enhance the client's psychological and social functions and improve social skills, interpersonal relationships, and communication. Nurses often use psychosocial interventions to help meet client needs and achieve final results in all practice sites (Videbeck, 2013).

\footnotetext{
Nursing Department, Faculty of Sport Education and Health Sciences

Universitas Pendidikan Indonesia

Email: andria.pragholapati@upi.edu
} 


\section{References}

Videbeck, Sheila L. (2008). Buku Ajar Keperawatan Jiwa, Jakarta : EGC.

Ade, M.S., Tjutju, Pragholapati, A., 2016. GAMBARAN KUALITAS HIDUP PADA LANSIA DI BALAI PERLINDUNGAN SOSIAL TRESNA WERDHA CIPARAY BANDUNG TAHUN 2016. http://ejurnal.stikesbhaktikencana.ac.id/file.php?file=preview_mahasiswa\&id=532\&cd=0b2173 ff6ad6a6fb09c95f6d50001df6\&name=JURNAL\%20SAKINAH\%202016.pdf.

Andria Pragholapati, M.L., 2017. HUBUNGAN MASALAH KESEHATAN JIWA DENGAN STRATEGI KOPING SESEORANG YANG MENGALAMI PERCERAIAN DI KOTA BANDUNG, in: Seminar Nasional Dan Workshop Keperawatan " Penguatan Profesi Keperawatan Dalam Peningkatan Pelayanan Keperawatan" Continuum of Care Dari Ketergantungan Menuju Kemandirian Hidup Yang Berkualitas. ISBN: 978-602-14422-8-9.

Andria Pragholapati, R., 2018. DEVELOPMENT OF THE INDONESIAN NATIONAL QUALIFICATIONS FRAMEWORK FOR NURSING CURRICULUM, in: International Conference on Education and Regional Development 3rd (ICERD) 2018 "Curriculum for Generation of Discruptive and 4th Industry Revolution Era." p. 44.

Andria Pragholapati, R.M., 2017. HUBUNGAN BULLYING DENGAN KEMAMPUAN SOSIAL PADA REMAJA DI SMK MVP KOTA BANDUNG TAHUN 2017, in: Konferensi Nasional Keperawatan Kesehatan Jiwa XIV Di Kalimantan Selatan Tahun 2017.

Andria Pragholapati, T., 2018. HUBUNGAN PENGGUNAAN SMARTPHONE DENGAN KUALITAS TIDUR PADA REMAJA DI SMK X BANDUNG, in: Konferensi Nasional Keperawatan Kesehatan Jiwa XV Di Hotel Four Point By Sheraton Makassar Sulawesi Selatan. pp. 1-7.

Ardiana, F., Nurlianawati, L., Pragholapati, A., 2016. Gambaran Fungsi Kognitif Pada Lanjut Usia (Lansia) Di Panti Jompo Muhammadiyah dan Yayasan Pondok Lansia Tulus kasih.

Ariani, A., Pragholapati, A., Pratama, A.S., 2020. Information Communication Technology (ICT) In Midwifery Education: A Review of the Literature, in: The 3rd International Seminar on Global Health (ISGH) "Technology Transformation in Health Care for Better Life" Bandung, West Java, Indonesia. http://repository2.stikesayani.ac.id/index.php/isgh3/article/view/352, pp. 66-69. Ismawati, Y., Pragholapati, A., 2020. KEJADIAN GASTRITIS DI DESA CINUNUK WILAYAH KERJA PUSKESMAS CINUNUK KABUPATEN BANDUNG.

Ismawati, Y., Sumbara, Pragholapati, A., 2018. HUBUNGAN POLA MAKAN DENGAN KEJADIAN GASTRITIS DI DESA CINUNUK WILAYAH KERJA PUSKESMAS CINUNUK KABUPATEN BANDUNG.

Pragholapati, A., 2020. Self-Efficacy Of Nurses During The Pandemic Covid-19. 
Pragholapati, A., 2020. COVID-19 IMPACT ON STUDENTS. osf.io.

Pragholapati, A., 2020. RESILIENSI PADA KONDISI WABAH COVID-19.

Pragholapati, A., 2020. STRES KERJA PERAWAT YANG BEKERJA DI UNIT GAWAT DARURAT (UGD) RUMAH SAKIT AL ISLAM (RSAI) BANDUNG.

Pragholapati, A., 2020. MOTIVASI KERJA PERAWAT DI RUANG RAWAT INAP RSUD MAJALAYA KABUPATEN BANDUNG.

Pragholapati, A., 2020. MENTAL HEALTH IN PANDEMIC COVID-19.

Pragholapati, A., 2020. RESILIENSI PERAWAT YANG BEKERJA DI UNIT GAWAT DARURAT (UGD) RUMAH SAKIT AL ISLAM (RSAI) BANDUNG.

Pragholapati, A., 2020. NEW NORMAL “INDONESIA” AFTER COVID-19 PANDEMIC.

Pragholapati, A., 2019. THE EFFECT OF BRAIN GYM TO THE LEVEL OF DEPRESSION IN GERIATRIC AT BALAI PERLINDUNGAN SOSIAL TRESNA WERDHA CIPARAY BANDUNG. J. Sk. Keperawatan 5, 128-146.

Pragholapati, A., Munawaroh, F., 2020. RESILIENSI PADA LANSIA. J. Surya Muda 2, 1-8.

Pragholapati, A., Ulfitri, W., 2019. Gambaran Mekanisme Coping pada Mahasiswa Program Studi Sarjana Keperawatan Tingkat IV yang Sedang Menghadapi Tugas Akhir di Sekolah Tinggi IImu Kesehatan X Bandung. Humanit. J. Psikol. 3, 115-126.

Prasetyo M, D., Nurlianawati, L., Pragholapati, A., 2017. GAMBARAN TINGKAT KECEMASAN PADA PASIEN PRE OPERASI FIBROADENOMA MAMMAE DI RUANG GUNTUR RUMAH SAKIT TK II DUSTIRA CIMAHI TAHUN 2017.

http://ejurnal.stikesbhaktikencana.ac.id/mahasiswa.php?detail=mahasiswa\&id ....

Rahmawati, S.D., Mulyati, T., Pragholapati, A., 2015. HUBUNGAN BODY IMAGE DENGAN POLA DIET PADA REMAJA PUTRI DI SMAN 24 BANDUNG TAHUN 2015. http://ejurnal.stikesbhaktikencana.ac.id/file.php?file=preview_mahasiswa\&id ....

Rosmala, I., Jundiah, S., Pragholapati, A., 2017. TINGKAT KECEMASAN PADA KELUARGA PASIEN DI RUANG ICU RSUD MAJALAYA KABUPATEN BANDUNG TAHUN 2017. http://ejurnal.stikesbhaktikencana.ac.id/file.php?file=preview_mahasiswa\&id=517\&cd=0b2173 ff6ad6a6fb09c95f6d50001df6\&name=Jurnal\%20Imas\%20Rosmala\%202017.pdf.

Septriani, D., Sari, Y.R., Pragholapati, A., 2019. The Relationship of Social Support With the Anxiety Level of Parents of Children with Thalassemia of Pre-School Age that Works in the Activities of Blood Transfusion in Hospital " $X$ " Bandung, in: The 2nd Bandung International Conference on Collaborative Health Research Research. Prama Grand Preanger Hotel Bandung, West Java, Indonesia 7th - 8th of October 2019. p. 12. 


\title{
Editorial
}

\author{
Virgona, A., Pragholapati, A., 2019. Enhancing Critical Thinking Skills in Nursing Higher \\ Education in Preparation for the Industrial Revolution 4.0: Literature Review, in: The 3rd \\ International Seminar on Global Health (ISGH) "Technology Transformation in Health Care for \\ Better Life" Bandung, West Java, Indonesia.
}

